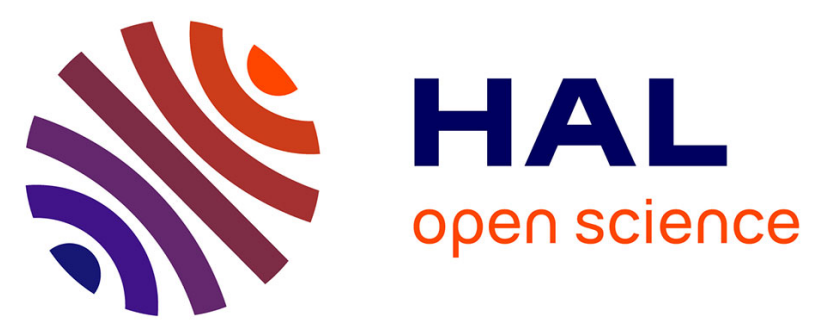

\title{
Unintended Formation of a 26-Membered Cycle in the Course of a Novel Approach to Myricanol, a Strained $[7,0]$-metacyclophane
}

Paul Massé, Sabine Choppin, Lucia Chiummiento, Gilles Hanquet, Francoise Colobert

\section{To cite this version:}

Paul Massé, Sabine Choppin, Lucia Chiummiento, Gilles Hanquet, Francoise Colobert. Unintended Formation of a 26-Membered Cycle in the Course of a Novel Approach to Myricanol, a Strained [7,0]-metacyclophane. SYNLETT, 2019. hal-03075499

\author{
HAL Id: hal-03075499 \\ https://hal.science/hal-03075499
}

Submitted on 16 Dec 2020

HAL is a multi-disciplinary open access archive for the deposit and dissemination of scientific research documents, whether they are published or not. The documents may come from teaching and research institutions in France or abroad, or from public or private research centers.
L'archive ouverte pluridisciplinaire HAL, est destinée au dépôt et à la diffusion de documents scientifiques de niveau recherche, publiés ou non, émanant des établissements d'enseignement et de recherche français ou étrangers, des laboratoires publics ou privés. 


\section{Unintended Formation of a 26-Membered Cycle in the Course of a Novel Approach to Myricanol, a Strained [7,0]-metacyclophane}

\author{
Paul Massé ${ }^{a}$ \\ Sabine Choppin*a \\ Lucia Chiummiento*b \\ Gilles Hanquet ${ }^{a}$ \\ Françoise Colobert ${ }^{a}$ \\ a Laboratoire d'Innovation Moléculaire et Applications (UMR \\ CNRS 7042), Université de Strasbourg / Université de Haute- \\ Alsace, ECPM, 25 Rue Becquerel, 67087 Strasbourg, France. \\ ${ }^{\mathrm{b}}$ Department of Science, University of Basilicata, Via dell'Ateneo \\ lucano, 10, 85100 Potenza, Italy. \\ sabine.choppin@unistra.fr \\ lucia.chiummiento@unibas.it
}

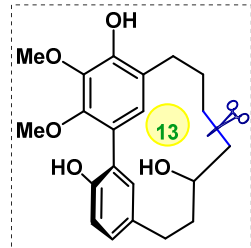

(士)-myricanol

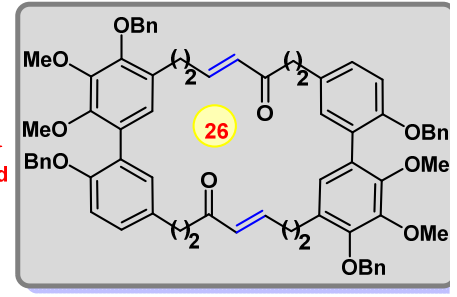

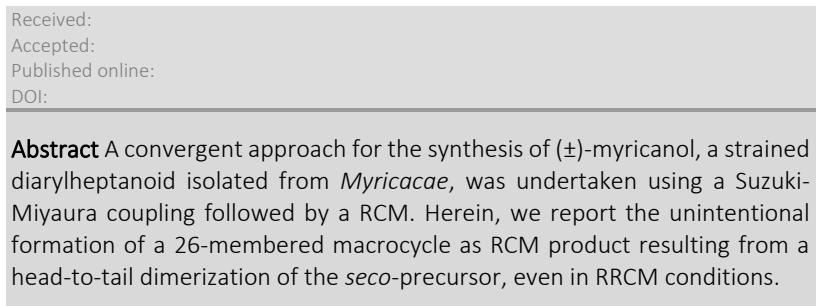

Key words myricanol, target-oriented synthesis, diarylheptanoid, natural product, macrocycle, Suzuki-Miyaura cross-coupling, RCM, Alzheimer's disease biological activities

Myricanol 1 was extracted from the stem bark of Myricacae species, trees that produce bayberries, and more particularly from Myrica Nagi in 1970 by Whiting and co-workers. ${ }^{1}$ There is a vivid interest in the community for this strained meta,metabridged phenolic diarylheptanoid $\mathbf{1}$ which displays a very intriguing structure with its biaryl system linked by an oxygenated aliphatic heptyl chain. ${ }^{2-3}$ Besides, it exhibits many different biological activities such as anti-oxidant and antiandrogenic. ${ }^{4}$ Very recently, it was discovered that $\mathbf{1}$ displays as well anti-inflammatory along with anti-obesity and anti-muscle atrophy properties. ${ }^{5}$ This [7,0]-metacyclophane 1 also features anti-cancer virtues. It was shown to undoubtedly strive against human lung adenocarcinoma A549 cells. ${ }^{6}$ Furthermore, Dickey et al found that 1 potently reduces the levels of the microtubuleassociated protein tau in both cultured cells and ex vivo mouse brain slices, which results in an anti-Alzheimer's disease effect, notably owing to the $(-)-\mathrm{a} S, 11 R$-myricanol enantiomer which has been separated by chiral HPLC.?

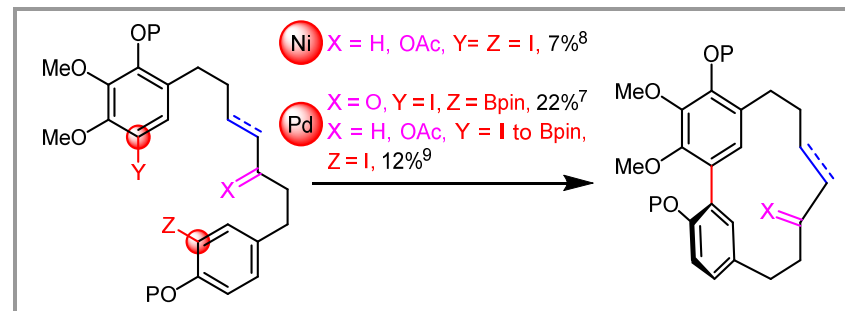

Scheme 1 State-of-the-art on macrocylizations leading to ( \pm )-myricanol

Three total syntheses have been previously described in a racemic way. The first one was reported by Whiting et al in 1983. ${ }^{8}$ They achieved the challenging macrocyclization in
$7 \%$ yield by a nickel-mediated intramolecular oxidative coupling from a linear diiodide diarylheptanoid. Dickey and coworkers reported in 2015 the second total synthesis of racemic myricanol 1.7 They performed an intramolecular SuzukiMiyaura cross coupling between an aryl boronic acid pinacol ester and an aryl iodide delivering the macrocycle in $22 \%$ yield. Colobert et al carried out a Suzuki-Miyaura domino reaction to obtain the expected 13-membered cycle in $12 \%$ yield (Scheme 1). ${ }^{9}$

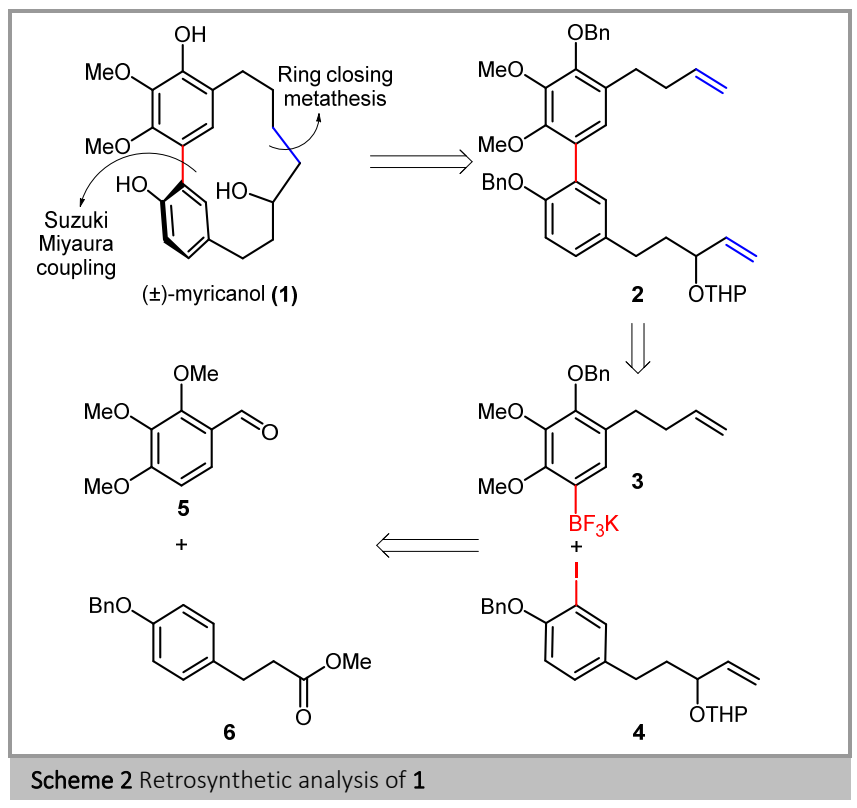

Based on our deep-rooted enthusiasm for the chemistry of bioactive natural products, ${ }^{10}$ we were eager to perform the total synthesis of this uncommonly strained compound. Meta-meta cyclic diarylheptanoids are considered as congested cyclophanes because of their high ring strain due to the short heptyl bridge. ${ }^{2 a, 3}$ As for all cyclic compounds, macrocyclization is the most critical step, which determines the overall efficiency of a synthetic route. ${ }^{3}$ To the best of our knowledge, endeavor of macrocyclization to prepare meta,meta-bridged diarylheptanoids in the literature other than by biaryl coupling have failed so far (Heck coupling and Thorpe-Ziegler reaction). ${ }^{11}$ However, none of those routes have envisioned a convergent approach of this 13-membered strained compound $\mathbf{1}$ via a 
sequence of two key reactions: a Suzuki-Miyaura coupling followed by a ring closing metathesis (RCM). RCM is often efficiently applied for the construction of strained natural compounds and with a large variety of substrates. ${ }^{12}$ For instance, Kundig et al prepared a strained 12-membered macrolactone bearing an ortho,meta diarylheptanoid performing a RCM in presence of HGII in an optimized yield of $37 \% .13$

A large variety of catalysts are available for RCM as GII, HGII, but also more exotic catalysts like Mauduit's (Umicore M71), Nolan's (Umicore M2) and Grela's (nG-I2) which could achieve this challenging macrocylization (Scheme 5). ${ }^{14}$ Herein, we describe a new convergent retrosynthetic pathway of $\mathbf{1}$ that could be arisen from $\mathbf{2}$ by RCM, itself stemming from the SuzukiMiyaura coupling from key building blocks $\mathbf{3}$ and $\mathbf{4}$, envisaged respectively from commercially available compounds $\mathbf{5}$ and $\mathbf{6}$ (Scheme 2).

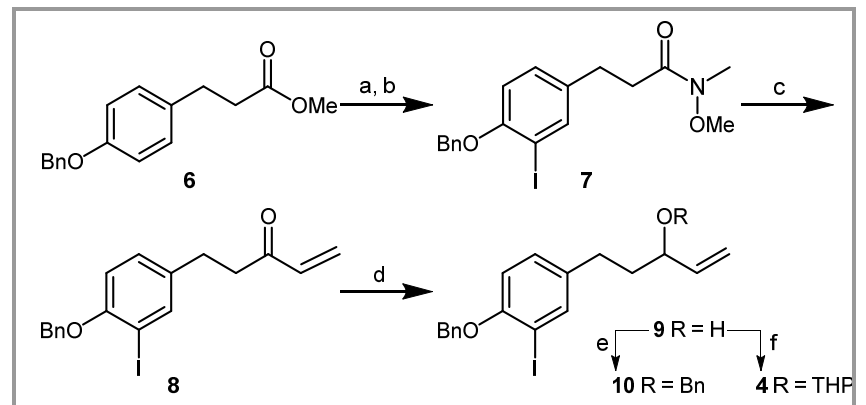

Scheme 3 Preparation of the first building-block 10 Reagents and conditions: (a) $\mathrm{CH}_{3} \mathrm{NHOCH}_{3} \cdot \mathrm{HCl}, \mathrm{AlMe}_{3}, \mathrm{PhMe}$, r.t., 24 h, $99 \%$; (b) $\mathrm{I}_{2}, \mathrm{Ag}_{2} \mathrm{SO}_{4}, \mathrm{CH}_{2} \mathrm{Cl}_{2}$, r.t. 3 days, $83 \%$; (c) vinylmagnesium bromide, $\mathrm{THF}, 0{ }^{\circ} \mathrm{C}, 1 \mathrm{~h}, 99 \%$; (d) $\mathrm{NaBH}_{4}$, $\mathrm{CeCl}_{3} \cdot 7 \mathrm{H}_{2} \mathrm{O}, \mathrm{MeOH},-78{ }^{\circ} \mathrm{C}, 0.5 \mathrm{~h}, 88 \%$; (e) $\mathrm{NaH}, \mathrm{BnBr}, \mathrm{Nal}, \mathrm{DMF}, 0{ }^{\circ} \mathrm{C}$ to r.t., 1.5 h, $91 \%$; (f) DHP, PPTS, $\mathrm{CH}_{2} \mathrm{Cl}_{2}$, r.t., 24 h, $79 \%$.

As depicted in Scheme 3, the first building block 10 has been synthetized in 5 steps on a multigram scale without any required purification from the readily available benzylprotected phenol 6.15 The ester moiety was derivatized into the corresponding Weinreb amide in toluene in remarkable yield using $\mathrm{AlMe}_{3}$ and the corresponding hydroxylamine hydrochloride. The latter underwent a regioselective iodination in ortho position of the benzyl ether using $\mathrm{I}_{2}$ as well as $\mathrm{Ag}_{2} \mathrm{SO}_{4}$ to give 7 in $83 \%$ yield. ${ }^{9}$ Subsequent vinylation of the amide with a Grignard reagent allowed us to isolate the $\alpha, \beta$-unsaturated ketone $\mathbf{8}$ in a quantitative yield upon quick hydrolysis with a strong acid to avoid the formation of a side-product coming from the Michael addition of the released hydroxylamine onto 8. ${ }^{16}$ Luche reduction furnished 9 in $88 \%$ yield with complete chemoselectivity. Consecutive protection of the formed allylic carbinol as its corresponding benzyl ether afforded the first building block 10 with an overall yield of 58\%. A variant protecting group (4, bearing a THP group) was envisaged to perform the remainder of the synthesis.

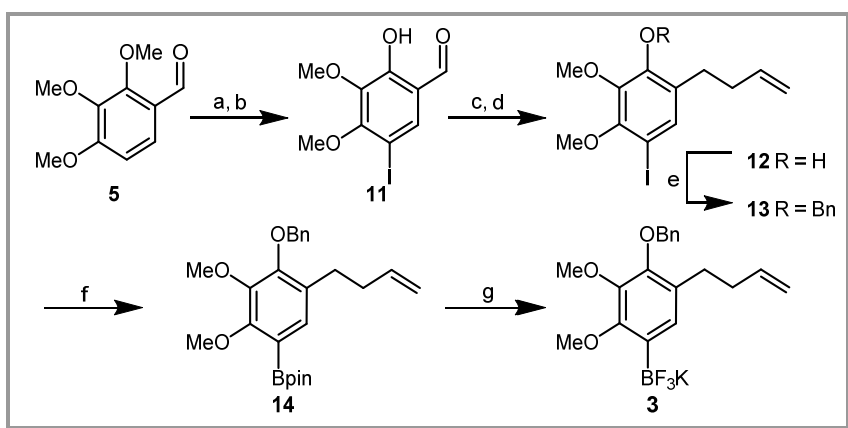

Scheme 4 Preparation of the second coupling partner 3 Reagents and conditions: (a) $\mathrm{AlCl}_{3}, \mathrm{CH}_{2} \mathrm{Cl}_{2}$, r.t., 3 h, $81 \%$; (b) $\mathrm{I}_{2}, \mathrm{Ag}_{2} \mathrm{SO}_{4}, \mathrm{CH}_{2} \mathrm{Cl}_{2}$, r.t., 3 days, 51\%; (c) allylmagnesium bromide, THF, $0{ }^{\circ} \mathrm{C}, 0.5 \mathrm{~h}, 87 \%$; (d) i. TES, TFAA, $\mathrm{CH}_{2} \mathrm{Cl}_{2}, 0{ }^{\circ} \mathrm{C}, 1.5 \mathrm{~h}$; ii. TBAF, THF, $70 \%$; (e) $\mathrm{BnBr}, \mathrm{NaH}, \mathrm{Nal}, \mathrm{DMF}, 1.5 \mathrm{~h}, 0{ }^{\circ} \mathrm{C}$ to r.t., $95 \%$; (f) i. $t$-BuLi, hexane, $-78{ }^{\circ} \mathrm{C}$; ii. $i$-PrOBpin, $-78{ }^{\circ} \mathrm{C}$ to r.t., 2.5 h; (g) $\mathrm{KHF}_{2}$, $\mathrm{H}_{2} \mathrm{O}, \mathrm{MeOH}$, r.t., $1.5 \mathrm{~h}, 89 \%$ (over 2 steps).

As outlined in Scheme 4, the synthesis of the second key coupling partner $\mathbf{3}$ started with commercially available trimethoxybenzaldehyde $\mathbf{5}$ which was regioselectively demethylated in ortho position of the aldehyde using a Lewis acid. The reaction has to be performed under $20^{\circ} \mathrm{C}$ to avoid a second competitive demethylation. Then, regioselective iodination of the aromatic cycle was accomplished and provided 11 exclusively in $51 \%$ yield. It should be noted that a complete conversion was observed; however, aryl iodide was trapped in the silver salts and remained unextractable; many experimental conditions were screened to improve yield, without any success. Upon allylation on the aldehyde with a Grignard reagent, homoallylic alcohol was afforded in excellent yield. Thereupon, the formed carbinol was cleaved using triethylsilane in acidic medium, ${ }^{17}$ followed by the addition of a solution of TBAF due to the resulting partial triethylsilylation of the phenol group, thus affording 12. Subsequently, the latter was subjected to a protection to give its corresponding benzyl ether $\mathbf{1 3}$ in 95\% yield. Aryl iodide 13 was treated with $t$-BuLi and isopropoxypinacolborane at $-78^{\circ} \mathrm{C}$ in dry hexane to provide 14 as a boronic acid pinacol ester. Finally, $\mathbf{3}$ was prepared on exposure to an aqueous solution of $\mathrm{KHF}_{2}$ in $\mathrm{MeOH}$ in $89 \%$ yield over two steps. $\mathbf{3}$ was reached in 7 steps with an overall yield of $25 \%{ }^{18}$

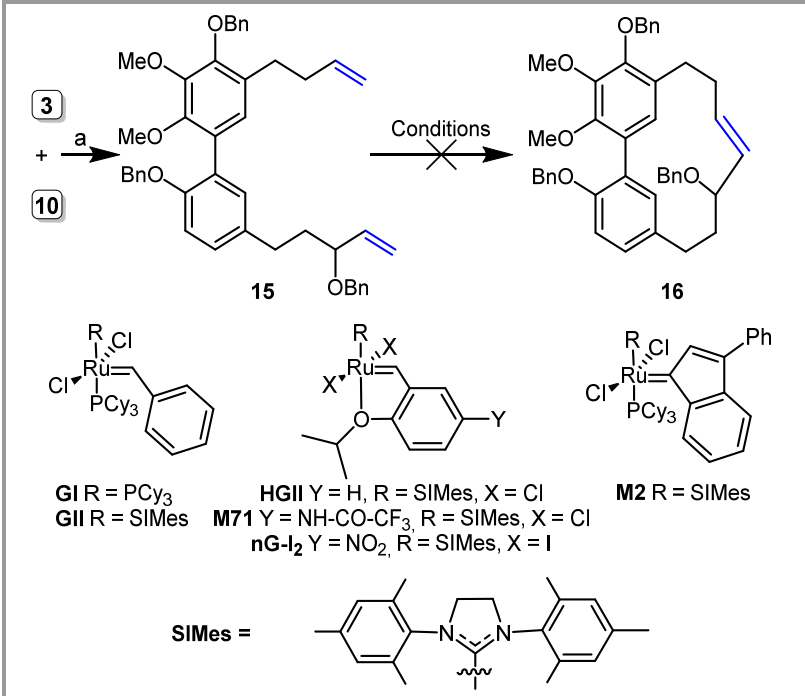

Scheme 5 First RCM attempts. Reagents and conditions: (a) $\mathrm{Pd}\left(\mathrm{PPh}_{3}\right)_{4}, \mathrm{~K}_{2} \mathrm{CO}_{3}$, TBAB, $\mathrm{H}_{2} \mathrm{O}, 100{ }^{\circ} \mathrm{C}, 16 \mathrm{~h}, 83 \%$. 
With both partners $\mathbf{3}$ and $\mathbf{1 0}$ in hand, we were able to synthetize the biaryl $\mathbf{1 5}$ by Suzuki-Miyaura coupling in the presence of palladium( 0 ) (Scheme 5). We have to point out that with the pinacol boronic ester 14, no reaction occurred; also, we were never able to synthetize the corresponding boronic acid, justifying the selection of the more reactive trifluoroborate salt. ${ }^{19}$ Moreover, the yield was low when the reaction was performed in dioxane (28\%). By modifying the ratio dioxane $/ \mathrm{H}_{2} \mathrm{O}$ up to $\mathrm{H}_{2} \mathrm{O}$ only, yield was increased to $83 \%$. With Buchwald conditions (palladium(II) acetate and SPhos ligand), we ended up with the isomerization of the terminal double bond.

To finalize the preparation of myricanol 1, first RCM assays were next attempted with the seco-precursor 15 by screening various solvents $\left(\mathrm{CH}_{2} \mathrm{Cl}_{2}\right.$, PhMe, DCE, $\left.\mathrm{Et}_{2} \mathrm{O}, \mathrm{H}_{2} \mathrm{O}\right)$ catalysts (GI, GII, HGII, M71, M2) and temperatures (from 25 to $110^{\circ} \mathrm{C}$ ). None of those experimental conditions gave us rise to the expected cyclized compound 16 even in the required high dilution conditions (Scheme 5). The benzyl-protected allylic alcohol being a type III olefin, ${ }^{20}$ hence less reactive, we therefore tried with the free allylic alcohol along with its corresponding $\alpha, \beta$ unsaturated ketone (likely to be more prone to macrocyclize due to the presence of the $\mathrm{sp}^{2}$ carbon center). Notwithstanding, it was impossible to deprotect regioselectively the benzyl group on the allylic alcohol versus the benzyl-protected phenols. Consequently, we tried the Suzuki-Miyaura coupling between our trifluoroborate salt $\mathbf{3}$ and ketone $\mathbf{8}$. Unfortunately, we could not access 18 directly (Path A, Scheme 6). Ketones are apparently not compatible with those conditions. Hence, we then attempted the coupling with $\mathbf{9}$ bearing the free hydroxy group instead, which afforded $\mathbf{1 7}$ in order to get by its further oxidation the corresponding ketone 18. In this way, $\mathbf{1 7}$ was obtained in low yield (Path B, Scheme 6). Based on these results, we further proceeded to a three-step sequence using 4 (THPprotected $\mathbf{9}$ derivative) that was coupled with $\mathbf{3}$ to obtain biaryl 2 in excellent $86 \%$ yield. Finally, removal of THP group and oxidation using $\mathrm{MnO}_{2}$ followed smoothly (Path C, Scheme 6).

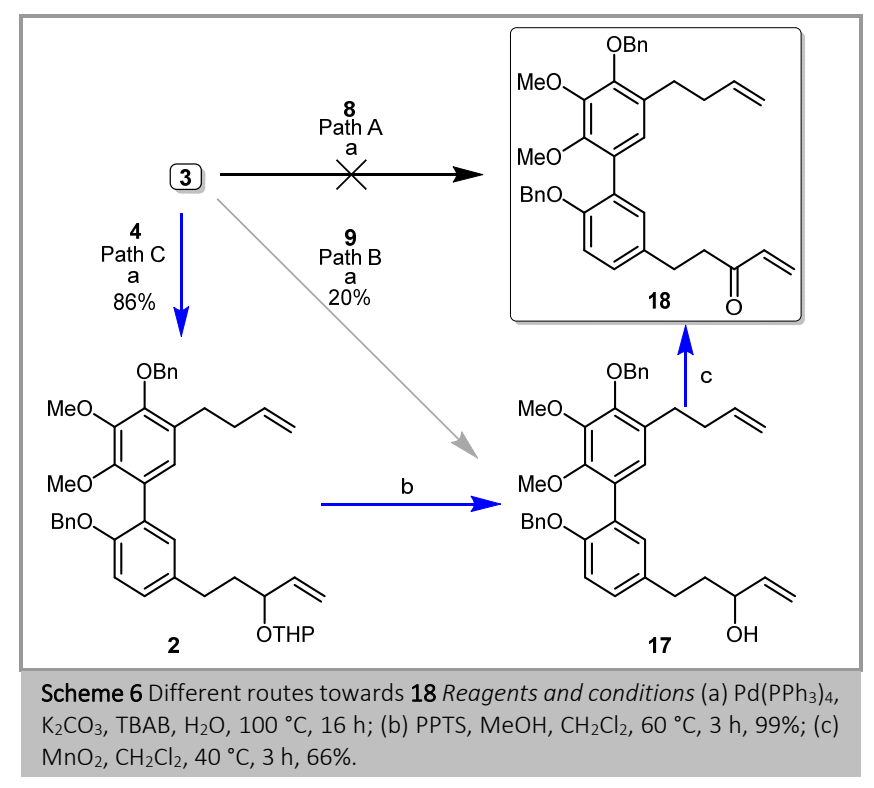

Further RCM attempts on $\mathbf{1 7}$ gave us unexpected results: we obtained two regioisomers 19 and 19'. Allylic alcohol isomerized into the corresponding ethyl ketone, ${ }^{21}$ and terminal double bond isomerized once, but also twice to be conjugated with the aromatic core (both compounds were obtained in a 1:1 ratio). ${ }^{22}$ The failure of the RCM of $\mathbf{1 7}$ could be explained by the free rotation of the biaryl axis which increase the difficulty of the two terminal alkenes to cross path. The presence of a $\mathrm{Csp}^{3}$ leads also to a more strained chain compared to the presence of a $\mathrm{Csp}^{2}{ }^{23}$ As for RCM attempts on $\mathbf{1 8}$, we were quite pleased to see by ${ }^{1} \mathrm{H}$ NMR that we obtained the expected cyclized compound. Nonetheless, we realized we formed the head-to-tail dimer $\mathbf{2 0}$ thus involving a C2 symmetry as evidenced from HR mass spectrum. ${ }^{24}$ Changing the solvent, the catalyst, lowering the concentration or adding the starting material via a syringe pump over a long period unfortunately did not circumvent our issue. (Table 1)

Table 1 Unexpected results in the course of RCM attempts on 19 and 20

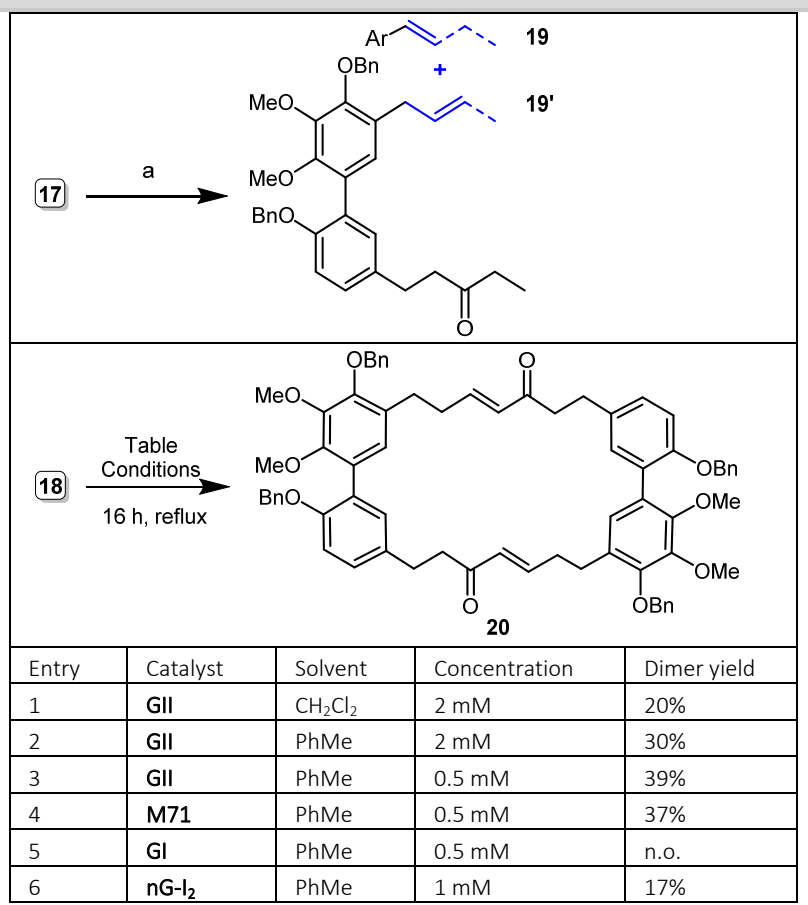

Reagents and conditions (a) GII, PhMe $(2 \mathrm{mM}), 110^{\circ} \mathrm{C}, 16 \mathrm{~h}, 35 \%$.

To overcome this synthesis drawback, we next sought to solicit the concept of Relay RCM (RRCM). ${ }^{25}$ RRCM involves the incorporation of a temporary pentenyl tether containing a terminal olefin to initiate the catalytic process. Once you add the catalyst, the ruthenium carbene can be formed on the terminal olefin, a 5-membered ring is extruded which leads to the desired metal carbene that can undergo further cyclization. Porco et al reported in 2004 the synthesis by RRCM of oximidine III, a 12membered macrocycle. ${ }^{26}$ They managed to obtain a yield of $71 \%$ for the macrocyclization step whereas with a classical RCM they could not get any traces of the expected compound. In our case, we chose to put a malonate group onto the temporary tether to improve the efficiency of our RRCM by dint of the Thorpe-Ingold effect. ${ }^{25}$

Starting from 9, we performed the cross-metathesis with dimethyl allylmalonate in the conditions described by Lipshutz et al, with a surfactant and copper iodide as an additive thus affording 21.27 Subsequently, both deprotonation of the 
methylene-active malonate motif followed by the trapping with allyl bromide and protection of the allylic alcohol with a THP group were quantitative. THP was a protecting group of choice given that it is easily accessible and easy to orthogonally deprotect. Afterwards, the Suzuki-coupling between $\mathbf{2 2}$ and $\mathbf{3}$ was implemented in a great yield and RRCM assays were attempted. RRCM assay on $\mathbf{2 3}$ was not conclusive: we extruded the 5-membered ring but the formed carbene did not react further, we therefore ended up with $\mathbf{2}$. We proceeded to the RRCM on free allylic alcohol $\mathbf{2 4}$, but we obtained the same results as with the RCM: isomerization of allylic alcohol into ethyl ketone and isomerization of the terminal double bond. $\mathbf{2 5}$ bearing the carbonyl function ended up degraded in the RRCM conditions (Scheme 7).

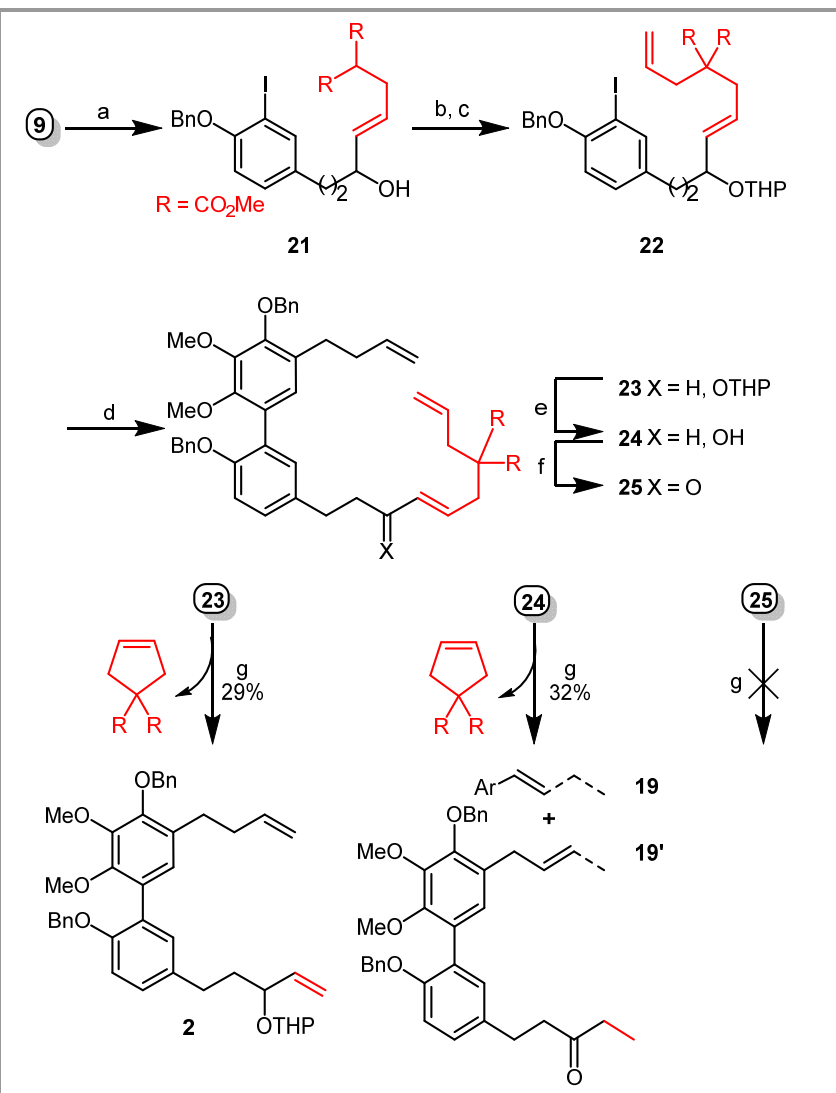

Scheme 7 Synthesis of RRCM precursor and subsequent RRCM attempts Reagents and conditions (a) dimethyl allylmalonate, GII, Cul, TPGS-750-M, $\mathrm{H}_{2} \mathrm{O}, 40{ }^{\circ} \mathrm{C}, 16$ h, 55\%; (b) DHP, PPTS, DCM, r.t., 16 h, 99\%; (c) $\mathrm{NaH}$, allylbromide, THF, $60{ }^{\circ} \mathrm{C}, 1.5 \mathrm{~h}, 99 \%$; (d) 3, $\mathrm{Pd}\left(\mathrm{PPh}_{3}\right)_{4}, \mathrm{~K}_{2} \mathrm{CO}_{3}, \mathrm{TBAB}, \mathrm{H}_{2} \mathrm{O}$, $100{ }^{\circ} \mathrm{C}, 16 \mathrm{~h}, 74 \%$; (e) PPTS, $\mathrm{MeOH}, \mathrm{CH}_{2} \mathrm{Cl}_{2}, 60{ }^{\circ} \mathrm{C}, 3 \mathrm{~h}, 99 \%$; (f) $\mathrm{MnO}_{2}, \mathrm{CH}_{2} \mathrm{Cl}_{2}$, $40{ }^{\circ} \mathrm{C}, 3 \mathrm{~h}, 64 \%$; (g) GII, PhMe (1 mM), $110{ }^{\circ} \mathrm{C}, 16 \mathrm{~h}$.

The free rotation of the biaryl axis combined with the high congestion of the desired compound could undeniably explain the uncompletion of the reaction. Accordingly, we attempted to make the less strained 14-membered cycle analogue, more prompt to undergo cyclization, as a proof of concept. Instead of using commercially available allyl Grignard reagent to prepare the RCM precursors, chain was introduced via an in situ homoallylic Grignard reagent on 11. Successive reduction, protection of 26, lithium-iodine exchange, trifluoroboration, Suzuki-Miyaura coupling on $\mathbf{2 7}$ and $\mathbf{4}$, deprotection and oxidation proceeded smoothly to procure 29 . Unfortunately, RCM attempts on $\mathbf{2 8}$ gave us notably a 28-membered macrocycle $\mathbf{3 0}$ among a myriad of isomerized products (adding benzoquinone to prevent isomerization did not succeed). ${ }^{28} \mathbf{2 9}$ with the ketone gave us also a head-to-tail dimer $\mathbf{3 1}$ in $37 \%$ yield (Scheme 8).

In conclusion, a 26-membered macrocycle and two 28membered macrocycles have been successfully synthetized using RCM in high dilution conditions. No traces of 13- or 14membered cyclized products were spotted even with RRCM. We can infer that the strain outpaces the reactivity, even in our attempts to prepare the 14-membered macrocycle.

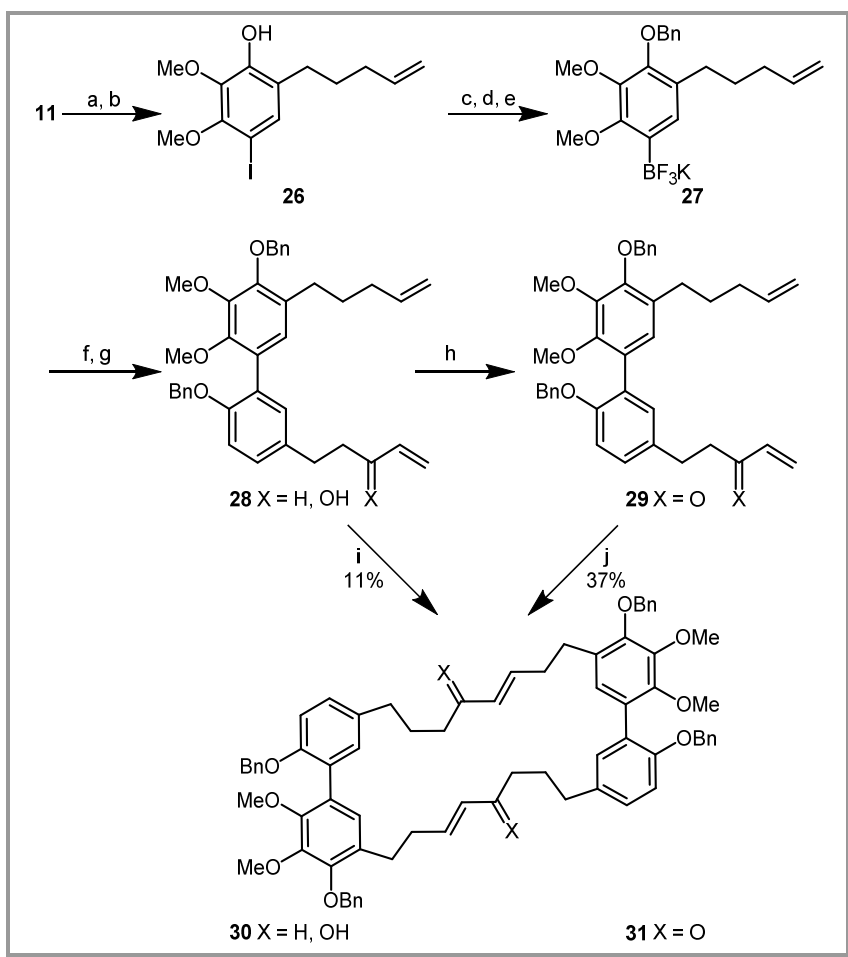

Scheme 8 Synthesis of corresponding 14-membered macrocycle precursor and subsequent RCM attempts Reagents and conditions (a) butenylbromide, $\mathrm{Mg}$, THF, $0{ }^{\circ} \mathrm{C}, 0.5 \mathrm{~h}, 98 \%$; (b) i. TES, TFAA, $\mathrm{CH}_{2} \mathrm{Cl}_{2}, 0{ }^{\circ} \mathrm{C}, 1.5 \mathrm{~h}$; ii. TBAF, THF, $80 \%$; (c) $\mathrm{BnBr}, \mathrm{NaH}, \mathrm{Nal}, \mathrm{DMF}, 1.5 \mathrm{~h}, 0{ }^{\circ} \mathrm{C}$ to r.t., $47 \%$; (d) i. $t$-BuLi, hexane, $-78{ }^{\circ} \mathrm{C}$; ii. $i$-PrOBpin, $-78{ }^{\circ} \mathrm{C}$ to r.t., $2.5 \mathrm{~h}$; (e) $\mathrm{KHF}_{2}, \mathrm{H}_{2} \mathrm{O}$, $\mathrm{MeOH}$, r.t., $1.5 \mathrm{~h}, 93 \%$ (over 2 steps); (f) $4, \mathrm{Pd}\left(\mathrm{PPh}_{3}\right)_{4}, \mathrm{~K}_{2} \mathrm{CO}_{3}, \mathrm{TBAB}, \mathrm{H}_{2} \mathrm{O}, 100{ }^{\circ} \mathrm{C}, 16 \mathrm{~h}$; (g) PPTS, $\mathrm{MeOH}, \mathrm{CH}_{2} \mathrm{Cl}_{2}, 60{ }^{\circ} \mathrm{C}, 3 \mathrm{~h}, 35 \%$ (over 2 steps); (h) $\mathrm{MnO}_{2}, \mathrm{CH}_{2} \mathrm{Cl}_{2}$, $40{ }^{\circ} \mathrm{C}, 3 \mathrm{~h}, 37 \%$. (i) GII, $\mathrm{CH}_{2} \mathrm{Cl}_{2}(1 \mathrm{mM}), 16 \mathrm{~h}, 11 \%$ (j) GII, PhMe (1 mM), 16 h, $37 \%$.

\section{Acknowledgment}

We thank the CNRS France (Centre National de la Recherche Scientifique) as well as the University of Strasbourg, and Paul Massé is grateful to the French ministry of research and development for financial support. We are also really grateful to Marc Mauduit who provided us his catalyst.

\section{Supporting Information}

YES (this text will be updated with links prior to publication)

\section{Primary Data}

NO (this text will be deleted prior to publication)

\section{References and Notes}

(1) Begley, M. J.; Campbell, R. V.; Crombie, L.; Whiting, D. A. J. Chem Soc. 1971, 3634. 
(2) (a) Jahng, Y.; Park, J. G. Molecules 2018, 23, 3107. (b) Alberti, Á.; Riethmüller, E.; Béni, S. J. Pharm. Biomed. Anal. 2018, 147, 13. (c) Zhu, J.; Islas-Gonzalez, G.; Bois-Choussy, M. Org. Prep. Proced. Int. 2000, 32, 505. (d) Sun, C.; Huang, H.; Xu, C.; Li, X.; Chen, K. Plant Foods Hum. Nutr. 2013, 68, 97.

(3) (a) Gulder, T.; Baran, P. S. Nat. Prod. Rep. 2012, 29, 899. (b) Joshi, B. S.; Pelletier, S. W.; Gary Newton, M.; Lee, D.; McGaughey, G. B.; Puar, M. S. J. Nat. Prod 1996, 59, 759.

(4) (a) Tao, J.; Morikawa, T.; Toguchida, I.; Ando, S.; Matsuda, H.; Yoshikawa, M. Bioorg. Med. Chem. 2002, 10, 4005. (b) Wang, M.; Liu, Y.; Pan, R. Le; Wang, R. Y.; Ding, S. L.; Dong, W. R.; Sun, G. B.; Ye, J. X.; Sun, X. B. Int. J. Mol. Med. 2019, 43, 2133. (c) Kubo, M.; Yamazaki, M.; Matsuda, H.; Matsuo, K.; Asanuma, Y. Biol. Pharm. Bull. 2002, 24, 259.

(5) (a) Shen, S.; Liao, Q.; Feng, Y.; Liu, J.; Pan, R.; Lee, S. M. Y.; Lin, L. Food Chem. 2019, 270, 305. (b) Shen, S.; Liao, Q.; Liu, J.; Pan, R.; Lee, S. M. Y.; Lin, L. J. Cachexia. Sarcopenia Muscle 2019, 10, 429. (c) CN108434127A (issued August 24th 2018).

(6) Dai, G. H.; Meng, G. M.; Tong, Y. L.; Chen, X.; Ren, Z. M.; Wang, K.; Yang, F. Phytomedicine 2014, 21, 1490.

(7) Martin, M. D.; Calcul, L.; Smith, C.; Jinwal, U. K.; Fontaine, S. N.; Darling, A.; Seeley, K.; Wojtas, L.; Narayan, M.; Gestwicki, J. E.; Smith, G. R.; Reitz, A. B.; Baker, B. J.; Dickey, C. A. ACS Chem. Biol. 2015, 10, 1099.

(8) Mohamed, S. E. N.; Whiting, D. A. J. Chem. Soc. Perkin Trans. I 1983, 2577.

(9) Bochicchio, A.; Schiavo, L.; Chiummiento, L.; Lupattelli, P.; Funicello, M.; Hanquet, G.; Choppin, S.; Colobert, F. Org. Biomol. Chem. 2018, 16, 8859.

(10) (a) Meidlinger, D.; Marx, L.; Bordeianu, C.; Choppin, S.; Colobert, F.; Speicher, A. Angew. Chem., Int. Ed. 2018, 57, 9160. (b) Norouzi-Arasi, H.; Salom-Roig, X. J.; Lanners, S.; Hanquet, G. Curr. Org. Synth. 2017, 15, 105. (c) Bensoussan, C.; Rival, N.; Hanquet, G.; Colobert, F.; Reymond, S.; Cossy, J. Nat. Prod. Rep. 2014, 31, 468. (d) Chiummiento, L.; Funicello, M.; Lopardo, M. T.; Lupattelli, P.; Choppin, S.; Colobert, F. Eur. J. Org. Chem. 2012, 188. (e) Ferreiro-Mederos, L.; Lanners, S.; Henchiri, H.; Fekih, A.; Hanquet, G. Nat. Prod. Res. 2009, 23, 256. (f) Bonini, C.; Chiummiento, L.; Pullez, M.; Solladié, G.; Colobert. F. J. Org. Chem. 2004, 69, 5015.

(11) (a) Dansou, B.; Pichon, C.; Dhal, R.; Brown, E.; Mille, S. Eur. J. Org. Chem. 2000, 1527. (b) Harrowven, D. C.; Woodcock, T.; Howes, P. D. Tetrahedron Lett. 2002, 43, 9327.

(12) (a) Lecourt, C.; Dhambri, S. ; Allievi, L. ; Sanogo, Y. ; Zeghbib, N.; Ben Othman, R.; Lannou, M.-I. ; Sorin ; Ardisson J. Nat. Prod. Rep. 2018, 35, 105 and references cited therein. (b) Cheng-Sanchez I.; Sarabia, F. Synthesis 2018, 50, 3749.

(13) Chausset-Boissarie, L.; Arvai, R.; Cumming, G. R.; Besnard C. E.; Peter Kundig, E. P. Chem. Commun., 2010, 46, 6264.
(14) (a) Clavier, H.; Caijo, F.; Borré, E.; Rix, D.; Boeda, F.; Nolan, S. P.; Mauduit, M. Eur. J. Org. Chem. 2009, 4254. (b) Tracz, A.; Matczak, M.; Urbaniak, K.; Skowerski, K. Beilstein J. Org. Chem. 2015, 11, 1823. (c) Boeda, F.; Clavier, H.; Nolan, S. P. Chem. Comm. 2008, 2726.

(15) Christiansen, E.; Due-Hansen, M. E.; Urban, C.; Merten, N.; Pfleiderer, M.; Karlsen, K. K.; Rasmussen, S. S.; Steensgaard, M.; Hamacher, A.; Schmidt, J.; Drewke, C.; Petersen, R. K.; Kristiansen, K.; Ullrich, S.; Kostenis, E.; Kassack, M. U.; Ulven, T. ACS Med. Chem. Lett. 2010, 1, 345.

(16) Gomtsyan, A. Org. Lett. 2000, 2, 11.

(17) Lalic, G.; Corey, E. J. Org. Lett. 2007, 9, 4921.

(18) Yuen, A. K. L.; Hutton, C. A. Tetrahedron Lett. 2005, 46, 7899.

(19) Molander, G. A.; Biolatto, B. J. Org. Chem 2003, 68, 4302.

(20) Chatterjee, A. K.; Choi, T. L.; Sanders, D. P.; Grubbs, R. H. J. Am. Chem. Soc. 2003, 125, 11360.

(21) Bäckvall, J.-E.; Andreasson, U. Tetrahedron Lett. 1993, 34, 5459.

(22) Jun Yue, C.; Liu, Y.; He, R. J. Mol. Catal. A Chem. 2006, 259, 17.

(23) Whiting, D. A.; Wood, A. F. Tetrahedron Lett. 1978, 19, 2335

(24) Preparation of $\mathbf{2 0}$ A solution of 18 ( 1 equiv., $51 \mathrm{mg}, 0.091 \mathrm{mmol}$ ) in toluene (180 $\mathrm{mL}$ ) was degassed for 30 minutes under a flow of argon. The reaction mixture was heated at reflux. Then, Grubbs $2^{\text {nd }}$ generation ( $20 \mathrm{~mol} \%, 15 \mathrm{mg}, 0.018 \mathrm{mmol}$ ) was added in one portion. The reaction mixture was stirred at reflux for $16 \mathrm{~h}$. The reaction mixture was filtered through a pad of both activated charcoal and silica gel and solvent was evaporated under reduced pressure to afford 20 (20 mg, $35 \mathrm{mmol}, 39 \%$ ) as an oil. ${ }^{1} \mathrm{H}$ NMR (500 MHz, Chloroform- $d$ ) $\delta 7.50-7.44(\mathrm{~m}$, $4 \mathrm{H}), 7.43-7.34(\mathrm{~m}, 6 \mathrm{H}), 7.27-7.20(\mathrm{~m}, 10 \mathrm{H}), 7.14-7.00(\mathrm{~m}$, $2 \mathrm{H}), 6.98(\mathrm{~d}, J=2.3 \mathrm{~Hz}, 2 \mathrm{H}), 6.87(\mathrm{~d}, J=8.4 \mathrm{~Hz}, 2 \mathrm{H}), 6.70-6.65$ $(\mathrm{m}, 4 \mathrm{H}), 5.97(\mathrm{~d}, J=16.0 \mathrm{~Hz}, 2 \mathrm{H}), 5.13-5.08(\mathrm{~m}, 4 \mathrm{H})$, $5.05-4.90(\mathrm{~m}, 4 \mathrm{H}), 3.99-3.82(\mathrm{~m}, 6 \mathrm{H}), 3.64(\mathrm{~s}, 6 \mathrm{H})$, $2.94-2.71(\mathrm{~m}, 8 \mathrm{H}), 2.57-2.48(\mathrm{~m}, 4 \mathrm{H}), 2.46-2.35(\mathrm{~m}, 4 \mathrm{H})$. ${ }^{13} \mathrm{C}$ NMR (125 MHz, Chloroform- $d$ ) $\delta 203.21,154.64,150.68$, $150.13,146.32,138.01,137.64,133.60,131.36,131.31$, $128.82,128.72,128.65,128.36,128.16,128.13,127.62$, $127.08,126.66,113.24,75.29,70.76,61.00,60.97,41.91$, 33.25, 29.84, 29.02. HRMS (ESI+): $\mathrm{C}_{70} \mathrm{H}_{68} \mathrm{NaO}_{10}\left([\mathrm{M}+\mathrm{Na}]^{+}\right)$: calcd 1091.4705, found 1091.4700.

(25) Hoye, T. R.; Jeffrey, C. S.; Tennakoon, M. A.; Wang, J.; Zhao, H. J. Am. Chem. Soc. 2004, 126, 10210.

(26) (a) Wallace, D. J. Angew. Chem., Int. Ed. 2005, 44, 1912. (b) Wang, X.; Bowman, E. J.; Bowman, B. J.; Porco, J. A. Angew. Chem., Int. Ed. 2004, 43, 3601.

(27) Lipshutz, B. H.; Petersen, T. B.; Abela, A. R. Org. Lett. 2008, 10, 1333.

(28) Hong, S. H.; Sanders, D. P.; Lee, C. W.; Grubbs, R. H. J. Am. Chem. Soc. 2005, 127, 17160. 